\title{
An Unusual Record of Greater Spotted Eagle (Clanga clanga) in Winter in Ankara, Turkey
}

\author{
Esra PER ${ }^{1,2,}{ }^{*}$, Emre ULUSOY2, Doğanay VURAL ${ }^{2}$
}

${ }^{1}$ Department of Biology, Faculty of Science, Gazi University, Teknikokullar, Ankara, Turkey

${ }^{2}$ DEDE Nature Team, İvedik Organize Sanayi Bölgesi 1122.cad. 1473.Sok. No:4-6-8 Yenimahalle Ankara, Turkey

\begin{abstract}
Received: 26.03 .2018
Accepted: 16.05 .2018

Available online: 28.05 .2018

Published: 30.06 .2018

Abstract: The population of the Greater Spotted Eagle is considered vulnerable (VU) globally according to the IUCN. Its population trend is decreasing. The wintering distribution still has not been studied enough in Anatolia and in the Middle East. This species is a local winter visitor around wetlands in western and southern Turkey. The main aim of this study is to give information about the new unusual record and evaluate historical wintering records for this species in Turkey. An adult Greater Spotted Eagle with Ukrainian ring was observed and photographed while it was roosting on the Scots Pine (Pinus sylvestris) tree around the wild boar carcass at an altitude of $1670 \mathrm{~m}$ in Soğuksu National Park, Ankara on January 24, 2017. There were no specific studies on this species in Turkey before. Only bird watching records are available about the species. The average number of wintering individuals in Turkey between 1990 and 2017 is 50. Specific surveys are needed to determine wintering population trends. Researches on wintering distribution in Turkey should be extended in the following years.
\end{abstract}

Keywords: The Greater Spotted Eagle, wintering, population, unusual observation, Soğuksu National Park, Turkey

\begin{abstract}
Ankara'da (Türkiye) Kış Mevsiminde Olağandışı Bir Büyük Orman Kartalı (Clanga clanga) Kaydı
Özet: IUCN'e göre Büyük orman kartalı'nın tüm dünyada popülasyonu Hassas (VU)'dır. Bu türün popülasyonu azalma eğilimindedir. Kışlama dağılımı hala Anadolu'da ve Orta Doğu'da yeterince incelenmemiştir. Bu tür Türkiye'nin batı ile güney kesimlerindeki sulak alanlarda ve çevresinde lokal olarak kış ziyaretçisidir. Bu çalışmanın temel amacı, olağan dışı bir gözlem hakkında bilgi vermek ve bu türün Türkiye'deki tarihsel kışlama kayıtlarını değerlendirmektir. Ankara'da 24 Ocak 2017'de Soğuksu Milli Parkı'nda 1670 m rakımda bir yaban domuzu karkasının etrafındaki Sarıçam (Pinus sylvestris) ağacına tünemiş olan, Ukrayna halkalı bir büyük orman kartalı gözlenmiş ve fotoğraflanmıştır. Türkiye'de bu tür hakkında spesifik bir araştırma yoktur. Sadece kuş gözlem kayıtları mevcuttur. Türkiye'de 1990-2017 yılları arasında kışlayan bireylerin ortalama sayısı 50'dir. Kışlama popülasyon eğilimlerini belirlemek için spesifik araştırmalara ihtiyaç duyulmaktadır. Önümüzdeki yıllarda Türkiye'de kışlama dağılımı hakkındaki araştırmalar genişletilmelidir.
\end{abstract}

Anahtar kelimeler: Büyük orman kartalı, kışlama, popülasyon, olağan dışı gözlem, Soğuksu Milli Parkı, Türkiye.

\section{Introduction}

The Greater Spotted eagle is accepted as a Vulnerable (VU) species globally (Birdlife 2018). It is facing a high risk of extinction in the wild with Vulnerable conservation status in the World (BirdLife International, 2004; 2015). It is affected by habitat loss. Its population trend is decreasing (Birdlife, 2018). There is a breeding region extending from Finland to China and there is a wintering region extending from Kenya to Japan. Throughout the twentieth century, their numbers have gradually decreased and many sub-populations have disappeared. As a result, they have a very fragmented distribution now (BirdLife, 2001). The Greater Spotted Eagle prefers marshes and large areas of water in winter in Slovakia. It avoids irrigated agricultural and urban areas. The waterfowl hunting has no effect on the spatial pattern of the Eagle's behavior; however, management of the water level in the reservoirs may affect the field utilization of the Greater Spotted Eagle (Perez et al., 2014).

The most important wintering areas for this species in the Mediterranean region are in Greece, Turkey, and Israel (Maciorowski et al., 2018). This species is a local winter visitor in western and southern Turkey (Kirwan et al., 2008; Maciorowski et al., 2014). It prefers to visit two

\footnotetext{
"Corresponding author: esraper@yahoo.com
}

thirds of the wetlands in the west of the country. This species is regularly observed in small numbers in the Black Sea (Kizılırmak Delta), Aegean, and Mediterranean regions in recent years (Göksu Delta). It is less common in Central Anatolia than it was in the late 1960s (Kirwan et al., 2008).

The current situation in Thrace and other places in the Marmara Region is unclear but it has been occasionally observed in the Marmara Lakes region, such as Lake Uluabat and Lake Manyas. It was observed more regularly in Meriç Delta between 1960s and early 1970s (Kirwan et al., 2008).

They are observed as small numbers of individuals regularly during their migration across Turkey. They can be observed in Istanbul and Belen Pass from the end of March to the beginning of May, and the middle of August to the beginning of November in autumn. For Ankara province (Central Anatolia), most 'winter' records last from the second week of February to the first week of March (Kirwan et al., 2008). There were several summer records in 1999 from the Southeast Anatolia (Karakas \& Kılıç, 2002).

It is known that after the breeding period, they migrate to the wintering areas. There is a small wintering 
population in Greece and Turkey (Meyburg et al., 2001). The wintering areas are probably very stable. This situation is very evident in the Göksu delta, Turkey. A female individual has been regularly wintering in this wetland on the Mediterranean coast since 1999 (Meyburg \& Meyburg, 2005). This species usually picks the shortest route via on Mediterranean coast in Turkey. The small number of individuals stops on migration way in Turkey. The wintering distribution still has not been studied enough in Anatolia and in the Middle East. The juvenile individuals follow a different migration way (Maciorowski et al., 2014). The Greater Spotted Eagle was recorded in winter season in the city center of Ankara province for the first time on February 20, 2005 by Geoff Welch. The second observation was from Tuz Lake in Ankara on December 13, 2013 by Alper Tüydeş (eBird, 2017). The main aim of this study is to give information about an unusual record and evaluate historical wintering records for this species in Turkey.

\section{Material and Methods}

This study was conducted in the Soğuksu National Park $\left(40^{\circ} 47^{\prime} \mathrm{N}, 32^{\circ} 65^{\prime} \mathrm{E}\right)$, Ankara province in Central Anatolia (Figure 1). This area is located at approximately $80 \mathrm{~km}$ north of Ankara city center. The national park has an area of $11.87 \mathrm{~km}^{2}$. The forests in the national park exhibit the characteristics of the European-Siberian vegetation. The mainly habitat of the national park includes Scots pine (Pinus sylvestris), Black pine (Pinus nigra), Caucasian fir (Abies nordmanniana), Common aspen (Populus tremula), Downy oak (Quercus pubescens), Common spikerush (Eleocharis palustris), and Steppe thyme (Thymus sipyleus). This forest is located in the transition zone from the Western Black Sea Region to the Central Anatolia.

The dominant vegetation in the area where the birds were detected is Scots pine (Pinus sylvestris), Black pine (Pinus nigra), and Common aspen (Populus tremula) forest at an altitude of $1670 \mathrm{~m}$.

The research has been going on with camera traps in the forest for two years on the ecosystem services of scavenger vertebrates. Dead wild boar carcasses are used for this research in the winter season. The lead bullet is hazardous to scavengers. Therefore, every dead wild boar is checked for lead bullets. This study was carried out on January 24, 2018. An adult Greater Spotted Eagle was observed and photographed by Emre Ulusoy with ring while it was roosting on the Scots pine (Pinus sylvestris) tree around the carcass. It did not show any scavenger activity here according to camera trap records and observations.

The database has been established for wintering records of this species. The sources of data are the observation records achieved between 1988 and 2017 from bird watching database (KuşBank/eBird; (available online at http://ebird.org/content/turkey/) and Trakuş, (available online at http://www.trakus.org/).

\section{Results and Discussion}

The color ringing of the Great Spotted Eagle is important in Europe for correlative cooperation and exchange of information among the national coordinators. The Great Spotted Eagle with ring can be observed by other ornithologists or bird watchers. In order to be able to obtain these data, it is important to inform about the ringing programs (Dravecký et al., 2008). An adult Greater Spotted Eagle was observed with grey color ring and code U15 in Soğuksu National Park, Ankara on January 24, 2018 (Figure 2). The ringing and resighting data was shared through the Turkish National Ringing Scheme and the Ukrainian Birds of Prey Research Center. The bird was ringed as a nestling by Sergey Domashevsky in the northwestern part of Ukraine, the Rivne region, on July 16, 2015.

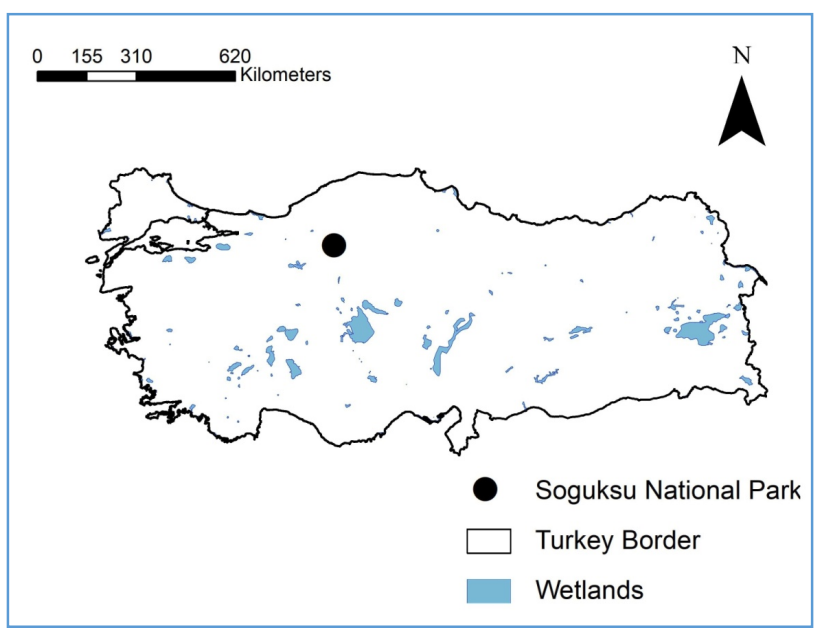

Figure 1: Study area

This species is not only the rarest but also the least investigated ringed and recovered species. Therefore, the possibility of ringing studies providing new information is low on this subject. Satellite telemetry has significantly improved the knowledge in this area (Meyburg \& Meyburg, 2005). This is a rare observation about this species and ringing feedbacks. Monitoring of scavenger birds by camera traps can be also important in terms of ringed bird feedback. Previously, a griffon vulture was observed and photographed in Turkey. Its ringing number was reported to Turkish National Ringing Scheme and related researchers. This is the second similar record in this research.

This species has wintering records in these wetlands in different years: Göksu Delta, Seyhan Delta, Kızılırmak Delta, Gediz Delta, Kavak Delta, Kocaçay Delta, Yumurtalık Lagoon, Enez Lagoon, Terkos Lake, Manyas Lake, Bafa Lake, Mert Lake, Uluabat Lake, Tuzla Lake, and İğneada Longoz Forest (eBird, 2017). The adult individual is apparently using the K1zılcahamam Forests at an altitude of $1670 \mathrm{~m}$. as a roosting area that seems to be a remarkable and rare record in winter. This is the highest altitude observation of winter records in Turkey. They commonly prefer low-altitude wetlands in Western Anatolia during the winter season. This species prefers to be away from people; therefore, the Soguksu National park could have been a shelter for this species. This record could be revealed as an unusual/a roosting record but there is no evidence for wintering. The weather condition can be effective in this rare observation.

This is an opportunistic predator and scavenger bird species. It is fed on small and medium-sized mammals, animal carcasses, and insects (Snow \& Perrins, 1998). Carrion is important in winter for this species (FergusonLees \& Christie, 2001). It feeds at wetlands in winter in Greece. Stands of trees are important for roosting and hunting. However, toxic carcasses are used by local 
farmers to eliminate foxes and dogs who are potential threats. For this reason, the susceptibility of poisoning and the extent of scavenging must be investigated (Alivizatos \& Papandropoulos, 2004). A single individual can winter on islands like Crete and mainly scavenge dead goats and sheep (Maciorowski, pers. obs.). Most of the individuals who were wintering in Israel feed with dead cranes (T. Krumenacker pers. Comm.) (Maciorowski et al., 2018). Feeding on small carcasses has been known but feeding on large carcasses is a rare record.

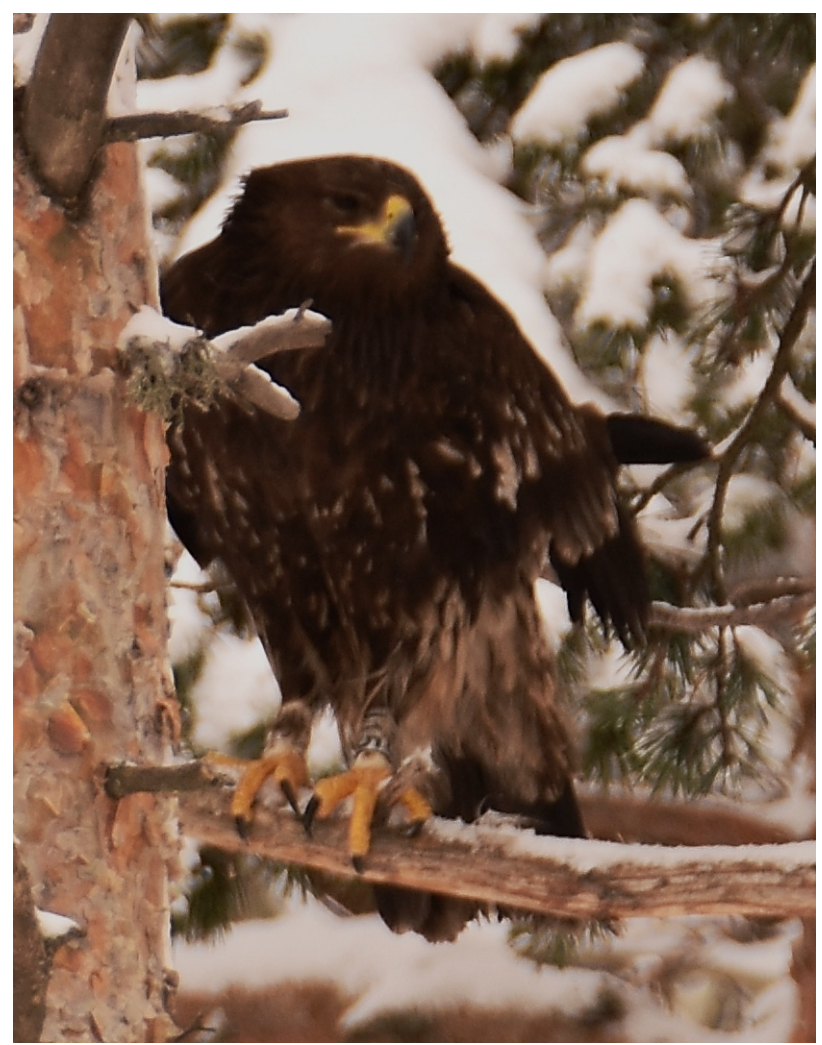

Figure 2: The Great Spotted Eagle with Ukrainian ring in Soğuksu National Park () Emre Ulusoy.

The research has been going on with camera traps and wild boar carcasses for two years on the ecosystem services of scavenger vertebrates in the forest but this species was observed for the first time in this area. The white-tailed eagle (Haliaeetus albicilla) was the most dominant scavenger species at the wild boar carcass on the observation day. The Great Spotted Eagle has a potential scavenger feeding behavior. An adult individual was observed around carcass but showed no scavenger activity in the Soğuksu National Park on that day. The camera trap might have missed some action or activity of the scavengers.

The number of wintering individuals in Turkey is 15 - 30 (K1lıç \& Eken, 2004). This number is based mainly on the bird reports and surveys in the IBAs. The species is mainly existed around large wetlands in western Turkey and the number of wintering individuals varies from year to year with respect to the eBird data. The average number of wintering individuals in Turkey between 1990 and 2017 is 50 according to eBird data and Kerem Ali Boyla's personal view. Size of the Greater Spotted Eagle wintering population in Turkey between $1989-2013$ is 44 - 72. This number is $13-18 \%$ of the Mediterranean population (Maciorowski et al., 2018). Göksu Delta,
Terkos Lake, and Manyas Lake are the major wintering sites for this species in Turkey based on the eBird data. The individuals of this species are regularly concentrated around these wetlands.

Recommended conservation actions for Turkey according to the EU action plan are to research for wintering populations and key roosting sites (Meyburg et al., 1997) and to raise public awareness on reducing illegal hunting on the migration route and wintering grounds of the Greater Spotted Eagle (Meyburg et al., 2001). This species is fully protected from hunting under the terrestrial hunting legislation but the public awareness for this species is low in Turkey.

There were no specific studies on this species in Turkey before. Only bird watching records are available about the species. Every study that provides new information to the literature is important to make an assessment. Specific surveys are needed to determine wintering population trends and anthropogenic pressure. Moreover, studies on wintering distribution in Turkey should be extended in the following years. This species may be observed in different wintering areas away from wetlands; therefore, this situation can be taken into account in conservation studies in the future.

Acknowledgement: We are very grateful to DEDE Nature Team members (Yunus Ayhan, Hasan Ulusoy, Ünsal Yılmazer, Niyazi Öztürk, and Mehmet Sanc1) for their contribution to the field work and to Kerem Ali Boyla and Sergey Domashevsky for their scientific contribution. We would like to thank Ministry of Forestry and Water Affairs, General Directorate of Nature Conservation and National Parks for field work permission and local support.

\section{References}

Alivizatos, H., Papandropoulos, D., \& Zogaris S. (2004). Winter diet of the Greater Spotted Eagle (Aquila clanga) in the Amvrakikos wetlands, Greece. Journal of Raptor Research 38: 371-374.

BirdLife International. (2001). Threatened birds of Asia: The BirdLife International Red Data Book. Cambridge, UK: BirdLife International, 3038p.

BirdLife International. (2004). Birds in Europe: population estimates, trends and conservation status. BirdLife Conservation Series No. 12 Cambridge, UK: BirdLife International, $374 \mathrm{p}$.

BirdLife International. (2018). Species factsheet: Clanga clanga. Retrieved from http:/ / www.birdlife.org on 16/02/2018.

Dravecký, M., Sellis, U., Bergmanis, U., Dombrovski, V., Lontkowski, J., Maciorowski, G., Maderič, B., Meyburg, B. U., Mizera, T., Stój, M. Treinys, R., \& Wójciak, J. (2008): Colour ringing of the Spotted Eagles (Aquila pomarina, Aquila clanga and their hybrids) in Europe - a review. Slovak Rapt J 2008, 2: 37-52.

eBird. (2012) eBird: An online database of bird distribution and abundance [web application], Cornell Lab of Ornithology, Ithaca, New York. Retrieved from http://www.ebird.org. on 02.02.2018.

Ferguson-Lees, J. \& Christie, D.A. (2001) Raptors of the world. Houghton Mifflin Company, New York. 992 p.

Karakaş, R., \& Kılıç, A. (2002). Birds of Göksu Dam (Diyarbakır) and new records in south-east Turkey. Sandgrouse 24:38-43.

Kirwan, G. M., Boyla, K. A., Castell, P., Demirci, B., Özen, M., Welch, H., \& Marlow, T. (2008). The birds of Turkey: a study of the distribution, taxonomy and breeding of Turkish Birds, Christopher Helm, London, $512 \mathrm{p}$

Kılıç, D. T., \& Eken, G. (2004). Turkey's Important Bird Areas-2004 Update. Doğa Derneği-BirdLife International, Ankara. [In Turkish]

Leronymidou, C., Pople, R., Burfield, I., \& Ramirez, I. (2016). The European Red List of Birds 2015. Bird Census News 2015, 28/1: 3-19. 
Maciorowski, G., Lontkowski, J., \& Mizera, T. (2014). The spotted eagle vanishing bird of the marshes. Agencja Promocyjno-Wydawnicza UNIGRAF, Bydgoszcz, 303 p.

Maciorowski. G., Galanaki. A., Kominos. T., Dretakis. M., \& Mirski. P. (2018). The importance of wetlands for the Greater Spotted Eagle Clanga clanga wintering in the Mediterranean Basin, Bird Conservation International, 1 - 9.

Meyburg, B. U., \& Meyburg, C. (2005). Tracking the endangered Greater Spotted Eagle. Tracker News 6(2): 4

Meyburg, B. U., Haraszthy, L., Strazds, M., \& Schäffer, N. (1997). European species action plan for Greater Spotted Eagle (Aquila clanga). European Union, Europe. 16 p.

Meyburg, B. U., Haraszthy, L., Strazds, M., \& Schäffer, N. (2001). European species action plan for Greater Spotted Eagle (Aquila clanga). In Schäffer, N., \& Gallo-Orsi, U. (Eds). European Union action plans for eight priority bird species (pp. 1 - 16). Luxembourg. European Commission, $247 \mathrm{p}$

Pérez-García, J. M., Sellis, U., \& Väli, Ü. (2014). Winter ranging behaviour of a greater spotted eagle (Aquila clanga) in southeast Spain during four consecutive years. Slovak Raptor Journal 8, 123-128.

Snow. D.W., Perrins. C.M. (1998). Birds of the Western Palearctic (Concise Edition 2 vols.), Volume 1. Oxford University Press, Oxford. 1694 p.

Trakuş (2018). Anonymous Information about the Species of Birds Living in Turkey's Natural Environment. Available from: http://www.trakus.org/ [Accessed 02.02.2018] 